\title{
REVIEW
}

UDC 612.392.61

doi: https://doi.org/10.15407/ubj93.04.005

\section{CHLORINE-BINDING STRUCTURES: ROLE AND ORGANIZATION IN DIFFERENT PROTEINS}

\author{
R. Yu. MARUNYCH ${ }^{凶}$, O. O. HRABOVSKYI, G. K. BEREZNYTSKYJ, \\ L. V. PYROGOVA, G. K. GOGOLINSKAYA, Ye. M. MAKOGONENKO \\ Palladin Institute of Biochemistry, National Academy of Sciences of Ukraine, Kyiv; \\ 凶e-mail: rostmarbiotech@gmail.com
}

Received: 29 September 2020; Accepted: 07 July 2021

The review focuses on chloride-binding structures in the proteins of bacteria, plants, viruses and animals. The structure and amino acid composition of the chloride-binding site and its role in the functioning of structural, regulatory, transport, receptor, channel proteins, transcription factors and enzymes are considered. Data on the important role of chloride-binding structures and chloride anions in the polymerization of fibrin are presented.

Ke y w o rds: chloride-binding site, chloride anion, protein structure, fibrin.

A mong the many ions present in cells and extracellular fluids, the chloride anion is very important. The anion is ubiquitous and its concentration is kept constant both in the cell and in the blood plasma where its level is 0.9\% (93-115 mM) in $\mathrm{NaCl}$ equivalent [1]. Most chloride anions are not bound, yet some bind to proteins and influence their spatial structure and its transformations [2].

In this article, we will review the main groups of proteins that bind chloride anions, their chlorine binding sites, and the similarities they share. We also will pay attention to the proteins' interaction with anions of carbonic acid and other anions of natural or artificial origin that can have effect on proteins' conformation. Of particular importance is the interaction with organic anions and negatively charged ionic detergents since the research in this field paves a way to the search for novel medicines.

Chlorine-binding proteins are functionally and structurally very diverse. They include transcription factors, enzymes (such as blood coagulation system proteins and kinases), $\mathrm{Cl}^{-}$transporters and $\mathrm{Cl}^{-}$chan- nels, receptors, respiration chain complexes, photosynthetic complexes, hemoglobin and albumin, structural proteins, messengers.

\section{Blood transport proteins}

One of the most important transport, oncotic and storage proteins of human blood plasma is albumin (HSA). It interacts with seven $\mathrm{Cl}^{-}$anions at neutral $\mathrm{pH}[3,4]$. The albumin molecule contains at least ten abnormal lysine and arginine residues which have pK 9.4 and are positively charged at neutral blood plasma $\mathrm{pH}$ what provides albumin interaction with chloride anions. Highly affine sites of albumin which bind the chloride anions have hydrophobic surroundings. The fact is confirmed by the interaction of albumin with negatively charged ionic detergents. Perhaps electrostatic interactions increase in a hydrophobic slit on albumin molecule. Since in the hydrophobic system there are positively charged groups of the basic amino acids residues, they prevent formation of chelate anion triplets. This makes entropic contribution to the free energy of chloride association with amino acid residues as wa- 
ter is released from their hydrate shells [3, 4]. The possibility of such mechanism of entropy growing as chloride binds to proteins was pointed out by [5].

Erythrocyte oxygen-transporting protein hemoglobin is another important chloride-binding protein of blood. The chlorine anion in hemoglobin acts as an allosteric regulator of the conformational transition between oxy- (R) and deoxy- $(\mathrm{T})$ forms of the molecule. The basic amino acids amino groups play an important role in the process of chloride binding and in the transition between molecule forms of hemoglobin. It has been shown in experiments with the acetylating agent methyl acetyl phosphate that the ability of hemoglobin to bind chloride anions depends on its conformational state. After binding of the chloride anion, the affinity of hemoglobin for oxygen decreases. The study of the acetylating agent action on the Bohr effect showed that the binding of chloride anions reduces the Bohr effect by $60 \%$ after acetylation of the $\mathrm{N}$-terminal $\alpha$-amino groups of Val-1 $(\alpha)$ and $\varepsilon$-amino groups of Lys-81 ( $\beta$ ) [6]; the residual $40 \%$ of the effect remain due to imidazole radical His-146( $\beta)$, acetylation of which by methyl acetyl phosphate does not depend on chloride. Five acetylated amino acid residues in bovine hemoglobin in oxygen-associated state were identified to interact with chloride and to make up chloride-binding sites. These were Val-1( $\alpha)$, Lys-99( $\alpha)$, Met-1( $\beta)$, Lys- $81(\beta)$, and Lys-103( $\beta$ ) [6].

Molecular modeling showed that chloride-binding site is elongated and stretches from one end of the central furrow of the hemoglobin to the other. Some of these sites make up channel-like structures which stretch to the ends of both axes passing through the protein globule. Binding of chloride, blockade of the positive charge in the middle of the channels or their covalent chemical modification such as the aforementioned acetylation or site-specific mutagenesis aimed at the creation of additional chloride-binding sites lead to lower affinity of the bovine hemoglobin to oxygen [6].

A similar study was done with random chemical modification of amino acid residues of the hemoglobin chains. The ability of the chloride anion and $\mathrm{CO}_{2}$ to affect binding sites has been studied. A methylating agent and the acetylating agent methyl acetyl phosphate with a radioactive label were used to study the $\mathrm{CO}_{2}$ and chloride binding respectively. Then there was carried proteolysis with trypsin and chymotrypsin and identification of the obtained peptides in order to find the oxygen-associated site which bound chloride and had an effect on the oxygen release kinetics [7]. Two chloride binding sites, that have an effect on affinity to oxygen were found in the $\alpha$-chain (Val-1 and Lys-99), three more in the $\beta$-chain (Met-1, Lys-81 and Lys-103). The amino acid positions here are the same as determined in the previous studies [6]. Molecular modeling of the hemoglobin molecule showed that chloride-binding sites which have an effect on the affinity to oxygen are situated symmetrically on the opposite sides of the molecule. These sites were sensitive to organic anions, the binding of which to hemoglobin decreased its affinity for oxygen. [7].

Another study was done using NMR of ${ }^{35} \mathrm{Cl}^{-}$ and peptide products of hydrolysis of human hemoglobin by carboxypeptidases A or B or their combination to identify chloride-binding sites. All products of hydrolysis as well as the native hemoglobin itself had two classes of chloride-binding sites: one with high affinity, the other with low affinity. The dependence of NMR spectra of ${ }^{35} \mathrm{Cl}^{-}$on the $\mathrm{pH}$ for samples obtained by proteolysis showed that chloride interacts with high affinity with a site near His- $\beta 146-A s p-\beta 94$ or the one near Val- $\alpha 1-A r g-\alpha 141$ amino acid residues. Sites with high affinity were strongly connected to the oxygen binding process, but this feature was lost in hydrolysis using both enzymes together. The connection correlated with conformational changes in the quaternary structure of the molecule. Organic phosphates such as inositol hexaphosphate competed for chloride anions with the high-affinity binding sites in native and cleaved hemoglobin. Competition disappeared in human hemoglobin cleaved by a mixture of carboxipeptidases [8]. NMR study of arterial and venous human blood showed that the chloride is bound more strongly in the second one. The phenomenon is linked to oxygen-dependent binding of chloride ion with hemoglobin. Their interaction determines or impacts a number of allosteric changes in hemoglobin, the Bohr's effect, Donnan equilibrium, Haldane effect and acid-base balance of the erythrocytes $[6,9]$. Thus, the affinity of the chloride anion for hemoglobin depends on the saturation of the latter with oxygen and vice versa.

Hemoglobin of animals from extreme habitats was shown to have an additional site of chloride binding. The interaction of oxygen and hemoglobin is known to be an exothermic process and so at lower temperatures the protein's affinity to oxygen should grow. Part of the energy is spent on 
releasing chloride anions from their binding sites. In the hemoglobin of several animals living in the North there was found an additional site of chloride binding made up by amino acid residues Lys $\beta 8$, Lys $\beta 76$ and His $\beta 77$. The proteins of animals from temperate latitudes also have additional sites. Additional site known for bovine hemoglobin arose from the substitution of $\beta 76$ Ala $\rightarrow$ Lys. An additional site of chloride anion binding in equine hemoglobin is formed as result of the interaction of two histidine residues, His $\beta 76$ and His $\beta 77$ [10].

\section{Transcription factors}

Transcription factors are another category of proteins able to bind chloride anions and change their conformation. These include AML1/Runx1 proteins. The proteins' action is based on interaction with certain DNA sequences, their identification and recruitment of DNA-dependent RNA polymerase to initiate expression of gene containing the signal sequence in its promoter site. The DNA-binding domain Runt of the transcription factor AML1/Runx1 is known to interact with chloride anions. The affinity of the interaction was studied by Wolf-Watz et al. [11]. Kd of the chloride ions was $34 \mathrm{mM}$. At addition of $\mathrm{CBF} \beta$ and formation of a 1:1 complex, $\mathrm{Kd}$ increased to $56 \mathrm{mM}$. Homology modeling showed that the chloride interaction site partially overlaps with the DNA interaction interface. The structure was investigated using NMR spectroscopy. NMR spectroscopy showed that DNA extrudes the chloride ion. It was found out that sites with high and low affinity exist and their interaction with DNA leads to extrusion of the chloride anion from the high-affinity site [11].

How does the chloride-binding domain Runt work that is homologous to STAT-1 and has Ig-similar folding? The Runt's heterodimer interacts with the chloride in 1.6 times weaker than the free monomer. The site which makes up the chloride-interaction interface is formed by amino acid residues R80, R139 (interact with the major groove of DNA), R139, R142 (interact with the minor groove of DNA); it is exactly R139, V170 that interact with the chloride, forming a complex of amino acid residues with chloride and DNA phosphate [12].

\section{Receptor proteins}

Receptor proteins, such as the red and green pigments of the human eye, interact with chloride anions. The binding of chloride to these pigment proteins causes a significant red shift in their maximum light absorption. Among the mutations of 18 positively charged amino acids, two residues (His197 and Lys200) proved to be very important for the functioning of the $\mathrm{Cl}^{-}$binding site. These two amino acids were structurally conservative in all pigments which absorb long waves, but they were absent in rhodopsins and pigments with short-wave absorption. The fact allows to suppose, that the evolutionary branch of long-wave pigments separated out after the common ancestor acquired the ability to bind the chloride anion, and thus the absorption maximum shifted into the long wave part of the range [13]. Chloride anions were shown to act similarly to bromide, yet the $\mathrm{F}^{-}$and sulfate ions had no effect on the shift, and $\mathrm{I}^{-}, \mathrm{NO}_{3}^{-}$, $\mathrm{SCN}^{-}$cause blue shift if there was a lack of chloride ions. Besides that the decrease in Kd for chloride from 150 to $30 \mathrm{mM}$ when the solution contains $\mathrm{SCN}^{-}$, indicates the ion's competition with the chloride for their common binding site. Double mutant H197E, K200Q had a specter with maximum at $500 \mathrm{~nm}$ (the shift moved from $530 \mathrm{~nm}$ relative to wild type) and did not depend on chloride. Experiments with mutants (separately for His197 and Lys200) allowed to establish that the green and red pigments bound chloride by His197, yet other experiments with site-targeted mutagenesis showed Lys200 also takes part in the interaction with chloride [13].

Two more receptors able to interact with chloride are cell surface receptors that react with mediator substances. The membranous receptor for glutamate is modulated by $\mathrm{Cl}^{-}$ions as shown by [14]. Ions binding is obligatory for the functioning of many mechanisms of neurotransmission, in particular for GPCRs which bind $\mathrm{Na}^{+}$. The authors identified two chloride-binding pockets in the extracellular domain of the metabotropic glutamate receptor 2 (mGlu2). One chloride binding site was found in the first lobe of the receptor extracellular domain; the site was conservative among the mGlu and LIVBP receptor families. By this site mGlu2 is closely related to the receptor of natriuretic peptide (NPR-A) [15].

Analysis of sequences of NPRs, mGluRs and class C of GPCRs (calcium-sensing receptor, smell receptor 5.24, taste receptor T1R3 [16-18]) showed that Ser53 in NPR-A , coordinating $\mathrm{Cl}^{-}$binding by the polar side chain, is very conservative, but is sometimes substituted with similar amino acids (threonine and asparagine) in other receptors [19, 20]. In the case of mGluRs, this serine is conservative in mGlu1, 2, 5 receptors, but can be replaced by threo- 
nine in mGlu3 and Group III mGluRs, where these residues are important for chloride retention. Other residues, which bind $\mathrm{Cl}^{-}$, are less conservative in these receptors. Chloride binding site lies between two very conservative short loops joined to two $\beta$-layers and two $\alpha$-coils ( $\beta 2-\alpha 2$ and $\beta 3-\alpha 3$ ), closely to the dimeric interface between coils $\alpha 2$ and $\alpha 3$. This placement indicates the structural role of the site, which is to stabilize the VFT conformation of the receptor by retaining two $\alpha$-helices, which allows the receptor to dimerize and activate.

The other chloride binding site is situated on the surface of the second lobe of the receptor, in the gap between two lobes close to the glutamate-binding pocket. The site is conservative in all mGluRs except mGlu2, where site 2 proved to be occupied by a negatively charged carboxyl group of Asp146 which functionally imitates the chloride ion. The carboxyl group forms hydrogen bonds with the $\mathrm{NH}$ moiety of Tyr216 and a salt bridge with Arg271, a residue which takes part in between-lobe interaction through cation interaction of Tyr144 and a salt bridge with Glu273 [21]. mGlu2 was less sensitive to chloride ions. The localization of the second site at the border between the two lobes suggests that the function of the chloride ion is to stabilize the closed active conformation of the VFT during glutamate binding, causing contact between lobes 1 and 2 , which accelerates receptor activation. The authors found very high functional positive cooperation for chloride and glutamate in mGlus (Hill coefficient is 6 for mGlu4), which indicates that small variation in chloride concentration can strongly influence glutamate sensitivity. This is the biological role of chloride in the functioning of the glutamatergic systems of the brain.

However, there is a receptor that loses its function in the absence of chloride ion, namely the atrial natriuretic receptor (ANPR) [20]. The extracellular domain of the receptor contains chloride near the ANP-binding site. The chloride is bound and immersed in the polypeptide structure. This is essential for the receptor - ANP interaction, and without it, full length recombinant ANPR does not bind the peptide. The function is restored when chloride or bromide is added. NMR spectroscopy showed that bromide was localized in the same place as the chloride. Also, the UF absorption spectra of chloride-containing and chloride-lacking receptors are different: the less negative by $215-230 \mathrm{~nm}$ and the more negative by $210 \mathrm{~nm}$ compared to ANPR which contains chloride. The chloride-lacking ANPR forms a dimer with altered characteristics unable to bind its ligand since for this requires conformational changes which occur only in the monomer. The structure of the chloride-binding site is very conservative in case of ANPR and receptors of guanylate cyclase receptors and glutamate receptors [20].

Reviewing of the structure of the chloridebinding site of ANPR shows that the chloride forms an ionic bond with the hydroxyl moiety of Ser53 and the NH moiety of Gly85, as well as to Cys86. The site also contains a unique cys-peptide Gly83-Pro84 and a disulfide bond Cys60-Cys86. Alignment the amino acid sequence of this region shows very conservative plots common for membrane-bound receptor of guanylyl cyclases and NPCR. Among these proteins, crystal structures were decoded for ANPR and NPCR [22-24]. In the aligned sequences, Ser53 in the ANPR (or GCA) is conservative only in GCB and NPCR. However, other receptors can also associate the chloride without this amino acid residue.

Alignment of the mCluR amino acid sequences in the region which corresponds to the chloridebinding site shows high conservatism of the amino acid residues, especially Ser and Thr which correspond to Ser53 in ANPR, and dipeptides Gly-Pro, Gly-Gly or Gly-Ala which correspond to Gly83Pro84 in ANPR. The peptides are in cys-configuration similar to such in ANPR. The chloride necessary for binding of ANP creates an autonomous switch mechanism for ANPR and ANP mediated natriuresis (under low chloride concentrations in the lumen), thus allowing a sodium readsorbtion regardless of ANP. This regulatory mechanism, hypothesized during ANPR research, could explain resistance to ANP under some physiologic conditions. A number of physiologic studies noted the part played by chloride in the ANPR control of mediated kidney regulation of salt balance [25-27].

\section{Transporters of chloride ions}

The erythrocyte protein of band 3 or AE1 is one of the fastest proteins of chloride/bicarbonate anion exchange which carries around 105 anions per second. It provides the so-called "chloride shift" which allows the erythrocytes to distinguish the metabolically active tissues that produce $\mathrm{CO}_{2}$ and absorb $\mathrm{O}_{2}$. The band 3 protein, carboanhydrase and hemoglobin function synergetically to provide transport of oxygen and $\mathrm{CO}_{2}$ [28]. Lysine, arginine and glutamic acid interact directly with anions in these 
proteins. $\mathrm{pH}$ titration experiments showed that extracellular histidine takes part in anion transfer. Interaction with 4,4'-Diisothiocyanohydrostilbene-2,2'disulfonic acid (DIDS) that inhibits anion exchange blocks one of the lysine residues on transporters. The inhibition is reversible [28]. Under alkaline $\mathrm{pH}$ the second isothiocyanate group of H2DIDS interacts with the lysine residue in the $35-\mathrm{kDa}$ fragment (Met-559 Val-911) of the band 3 protein, creating a bond with the NH2-terminal $60 \mathrm{kDa}$ fragment (Met-1 Tyr-553) and 35-kDa COOH-terminal fragment of the band 3 protein of erythrocytes. H2DIDS binds together Lys539 and Lys581 in the band 3 protein of erythrocytes identifying the site as necessary for anion transfer $[28,29]$.

In mammals, ClC- $1,-2,-\mathrm{Ka} /-\mathrm{Kb}$ are channels for $\mathrm{Cl}^{-}$anions in the plasmalemma while ClC-3 to ClC-7 are $2 \mathrm{Cl} / \mathrm{H}^{+}$exchange proteins in the endolysosomal membranes. The biological role of CLC has been mostly studied in mammals, but such structures are found in plants and model organisms such as yeasts and Caenorhabditis elegans [30]. CLC channels play a part in the electrical excitability, homeostasis of extra- and intracellular ions and their transepithelial transport while anion/proton exchange proteins regulate vesicular ion content and have an effect on endocytosis and lysosomal function of the cells [30].

It was found that the mutually opposite Nterminal sequences of the TM3 and TM10 coils make up an anion binding site in the Band 3 protein. Employing coils to bind anions is similar to such in a chloride-binding site of the prokaryotic $\mathrm{H}^{+} / \mathrm{Cl}^{-}$ ion exchanger [31, 32]. Initially the low-resolution $(8,5 \AA)$ electron microscopy of the Band 3 protein crystals showed a certain structural similarity between it and the prokaryotic ion exchanger [33-35]. Based on the UraA protein model, an atomic model of the Band 3 protein was constructed, which corresponds to the actual structure of the Band 3 protein [36]. It is assumed that the anion-binding site of the Band 3 protein may be located at the $\mathrm{N}$-terminal positively charged ends of short antiparallel helices TM3 and 10 (Fig. 2). The side chain Glu681 in TM8 can occupy the site in anion-poor conditions. It acts as an active site blocker or as a gate. Glu681 was found to be an H-binding site in the Band 3 protein which takes part in co-transport of $\mathrm{H}^{+}$and sulfate $[37,38]$. A mutation in a homologous residue in the Band 3 protein (E699Q) in mice resulted in a loss of the ability to carry out chloride-mediated anion exchange [39, 40]. E681Q mutation in human Band 3

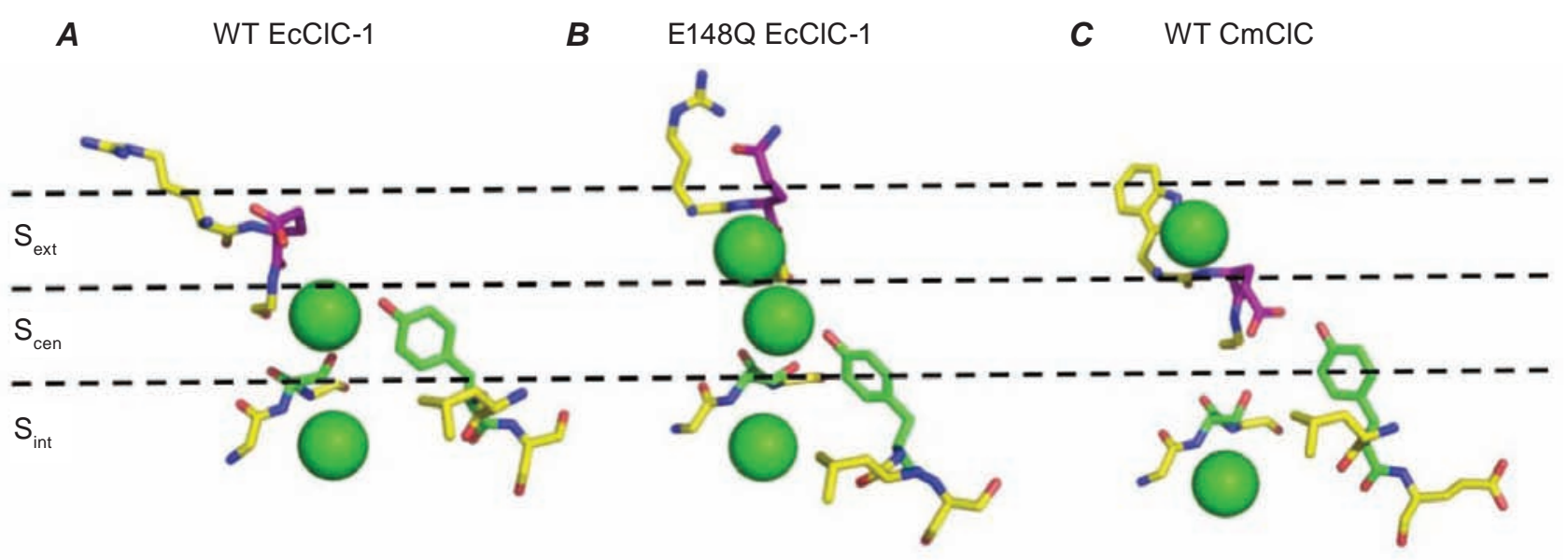

Fig. 1. Chloride ions transfer by transporters and their binding sites. The key amino acid residues which take part in the interaction with chloride anion to allow selectivity and the $\mathrm{Cl}^{-}$ions bound to the channels are shown for three different crystalline structures which are considered to present different conformations of CLC exchange proteins during a transport cycle. A: WT EcClC-1 (pdb 1OTS). B: mutant E148Q EcClC-1 (pdb 1OTU). C: WT CmClC (pdb 3ORG). The positions of the anion and the binding sites are shown by dashed lines. Glutamate which makes up the ionic gate (and Q148 in B) is shown by a red rod. Serine inside the channel (S107 in EcClC-1) and tyrosine situated in the channel (Y445 in EcClC-1) are marked by green rod. The outer site is occupied by the side chain of the glutamate residue of the ionic gate in $\mathrm{A}$, and the $\mathrm{Cl}^{-}$ion in $\mathrm{B}$ and $C$. The side channel of the ionic gate glutamate points outwards in B and occupies position $S_{c e n}$ in $C . S_{\text {ext }}$ is the extracellular space, $S_{c e n}$ is the membrane layer, $S_{i n t}$ is the intracellular space [30] 

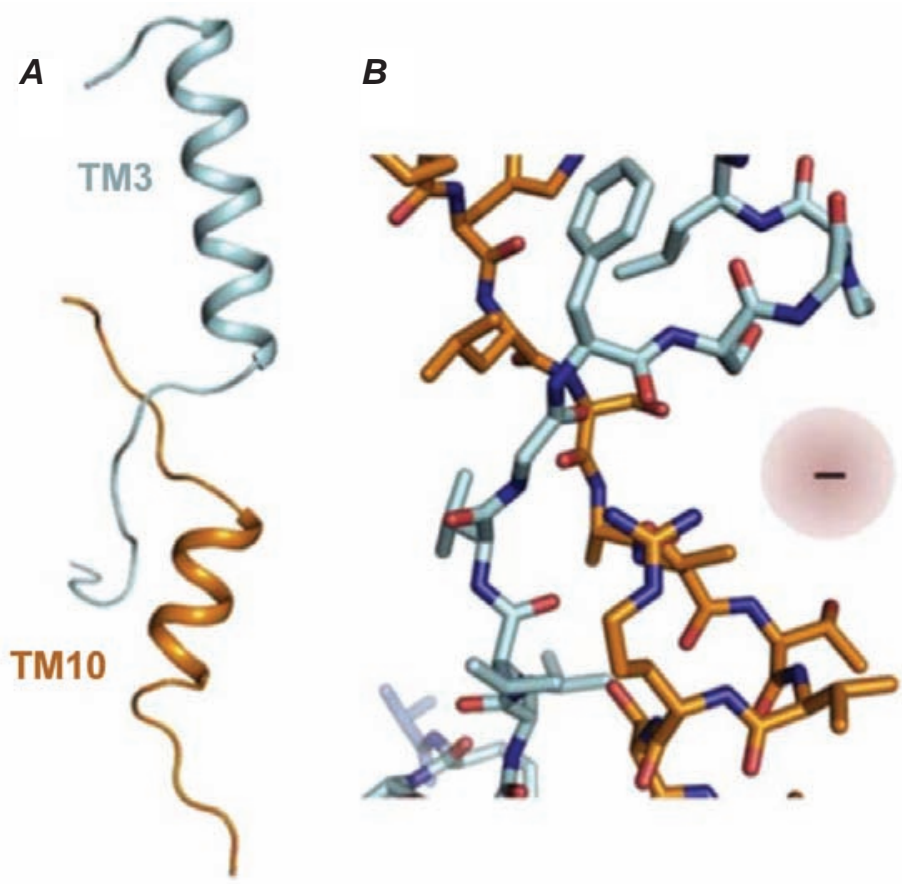

Fig. 2. Structure of the anion-binding site of the Band 3 protein (A), $N$-terminal helix of TM3 (blue) and 10 (brown). The positive dipoles of the fragments touch each other, creating an anion-binding site. (B) Anion (red gradient circle) near the intersection of two sequences. According to [31], the position of Glu681 corresponds to the active Glu241 site in the UraA protein. Interestingly, the side chain of Glu681 is $5.3 \AA$ from the side chain of the reactive H2DIDS Lys851 in TM13, which allows interaction between these two residues

protein also significantly disrupts the $\mathrm{Cl}^{-} / \mathrm{HCO}^{-}$exchange, but accelerates sulfate transport making it largely independent of $\mathrm{pH}$ [41]. The presence of a negative charge in Glu681 can prevent the binding of divalent ions such as sulfate due to anionic repulsion, while removing the charge in Glu681 will allow sulfate to bind.

Perhaps Lys851 is an ionic partner for Glu681 when it moves away from the anion-binding site. The relative positions of these two residues could be different in the Band 3 protein and change during the transport cycle. The side chain of Arg730 in the helix part of TM10 is turned to the active site of the Band 3 protein which is $7.5 \AA$ away from Glu681. Thus, Arg730 provides positively charged medium for the anions [32].

A very different type of the chloride-binding structure is found in the serotonin transporter (SERT). It has a chloride-binding site comprised of Ser-372 and Asn-368, containing Tyr-121 and Ser-336 and absent in the bacterial homologue [42]. Bacterial homologues - NSS proteins are transmembrane amino acid transporters of tryptophan, leucine, tyrosine etc. Like mammalian homologues, their action de- pends on sodium, but is completely independent of chloride. Two similar homologous models SERT and GAT-1 have been proposed and it has been shown that the localization of chlorides is the same in both structures. In both models chloride was coordinated by side chains of Tyr-121, Ser-336 and Ser-372 (in transmembrane helices (TMs) 2, 6, and 7, according to SERT nomenclature). This model, contrastingly, includes Asn-368 [43] (TM7) and according to [43] includes Gln-332 (TM6). Chloride binding stabilizes the oppositely charged binding site Na1 which has two coordinating residues (Ser-336 and Asn-368 in SERT) [43]. In chloride-independent prokaryotic transporters such stabilization is achieved due to the ionized group of the protein (Glu-290 in LeuT) $[43,44]$. Other residues that can coordinate chloride are contained in four helical structures that can take part in the transport cycle [45, 46]. Also for the neurotransmitters NSSs that symport $\mathrm{Na}^{+}$there were built two models with different architectures of the chloride-binding site based on mutagenesis and molecular modeling [42-44, 47, 48]. Both models agree that the chloride is coordinated by the Tyr47, Thr254, Ser290 residues (LeuT). Another model was 
proposed for quadridentate coordination of ligands Gln250 [44, 48] or Asn286 [42, 43]. According to $[44,48]$, the authors showed that $\mathrm{Cl}^{-}$forms coordinate bonds with side chains of the hydroxyl moieties of Tyr47, Ser290 and Thr254 and the amide group of Gln250. Asn286 does not have direct coordination bonds with the anion, but is in close proximity and has a hydrogen bond with the coordinating chloride Thr254. Analysis of the molecular dynamics of the authors showed that this proximity is stable, and Asn 286 may even occasionally enter the coordination range of binding with the chloride anion. The main task of the chloride is to maintain the structure and neutralize the positive charge during the transporter operating cycle. It is known that the chloride can regulate the activity of chloride glycinedependent channels. It is assumed that the action of the anion is directed to two binding sites that have an allosteric effect on the interaction with the ligand. However, the molecular details of the center structure have not yet been discovered [49].

\section{Different enzymes}

Regarding the effect of chloride on enzyme function and the role played by chloride binding structures, let us consider the site structure in the bacterial enzyme trehalose-6-phosphate hydrolase. It is known that the residues Arg201, Asn327, and Tyr365 provide the environment for the chloride ion, while the enzyme itself has $(\alpha / \beta) 8$ [50]. By site-specific mutagenesis it was found that mutant for these amino acids enzymes (R201Q/E/K, N327Q/D/K and Y365A/R) had lower or completely absent (the first two cases) enzymatic activity. Residues Arg201 and Asn327 are required for chloride binding and can interact with bromide and fluorine ions [50]. Another chloride-inhibited enzyme is WNK1 kinase, sensitive to the anion. The kinase triggers a cascade of reactions in which the final effectors are transporters of $\mathrm{Na}^{+}, \mathrm{K}^{+}$and chloride (NKCC), $\mathrm{Na}^{+}$and chloride (NCC), $\mathrm{K}^{+}$and chloride (KCC). Thus, the kinase regulates concentrations of $\mathrm{NaCl}$ and $\mathrm{KCl}$ in the cytosol [51]. It was found that chloride stabilizes the inactive conformation of WNK1, preventing activation and autophosphorylation of the kinase. Chloride directly interacts with the active site of the enzyme, binding to important for catalysis the lysine residue. The data allow to view the enzyme as a kind of chloride sensor. The chloride ion also hydrophobically interacts with Phe 283 in $\beta 3$, Leu 299 in $\beta 4$, Leu 369 in the DLG sequence of the subdomain 4 and
Leu371 in the $\alpha$ helix $3 / 10$. Nevertheless, the main interactions occur with Leu369, Gly370, Leu371 in the active center of the enzyme [51].

Another enzyme is bo-type ubiquinol oxidase, isolated from $E$. coli, which also has a chloride binding site that modulates the function of iron and copper of the binuclear active site. A possible role for the bound chloride is intramolecular electron transfer. To study the chloride part, the authors of [52] conducted a series of experiments on the preparation of a chloride-enzymatic complex under various in vitro conditions, such as the chloride-saturated UQO-412 and UQO-409 and the chloride-poor enzyme UQO-407, and studied their spectroscopic and enzymatic properties. They used anion-exchange chromatography to isolate the UQO-412 variant with the Soret peak at $412 \mathrm{~nm}$ in the air-oxidized state. The UQO-409 variant was derived from UQO-412 by extensive washing; it exhibited a $3 \mathrm{~nm}$ blue shift in absorption. UQO-407 was obtained from UQO409 by adding chloride ions to the buffer during all stages of enzyme complex purification. A further blue shift of the Soret peak and pronounced chloride-sensitive EPR signals were observed at $g=6$ and $g=3.15$, which is explained by the spin-spin exchange interaction in the binuclear center containing copper and iron ions. A kinetic study showed that the chloride bound to the chloride-binding site in UQO-407 with a K(d) of 3,5 mM [52]. The transfer of electrons from heme $b$ to heme o was also impaired in both UQO-409 and UQO-407, although the enzymatic activity in steady states of UQO was the same. According to the results, the bo-type ubiquinol oxidase isolated from E. coli has a chloride-binding site which controls the electromagnetic state of the heme-copper binuclear site. Presumably, for intramolecular electron transfer in the enzyme, diffusing molecules are required, which are not similar to bound chlorine ions [52]. However, the structure of the active site could not be identified.

Angiotensin-converting enzyme (ACE, peptidyl-dipeptidase A, EC 3.4.15.1) is a metallopeptidase of the gluzincin group. Mammalian cells produce two isoforms of the enzyme. The somatic isoform is found in most cells and tissues and has two homologous $-\mathrm{N}$ and $-\mathrm{C}$ domains containing $\mathrm{Zn}^{2+}$ dependent catalytic sites [53]. The testicular ACE isoform is synthesized only in the testicles and corresponds to the $\mathrm{C}$ domain of the somatic enzyme (except $67 \mathrm{~N}$ terminal amino acid residues) and has only one active site [54]. Two isoforms are encoded by the same 
gene, but have two different transcription start sequences [55]. A unique feature of this enzyme is its activation by the chloride anion. The spatial structure of the $\mathrm{C}$ domain of human ACE and its complex with inhibitors was recently found by X-ray analysis $[56,57]$. It was shown that the single domain of the human enzyme has two chloride-binding sites $20 \AA$ apart. The first chloride-binding site is $21 \AA$, and the second is $10 \AA$ apart from the $\mathrm{Zn}^{2+}$ ion in the active site [56]. According to the structural data, the C-domain of this enzyme has the following microenvironment of two chloride anions [58]: the first chloride anion (Cl1, further from the $\mathrm{Zn}^{2+}$ active site) is bound to two Arg residues and is surrounded by a hydrophobic shell of four Trp residues. The other one (Cl2, closer to the $\mathrm{Zn}^{2+}$ of the active site) is bound to Arg residue. This has crucial importance for the ACE sensitivity to chloride as previously shown [59]. Tyrosine and some other hydrophobic residues also belong to the $\mathrm{Cl} 2$ environment. For Cl1, the contacting residues are Arg 186, Arg 489, Trp 182, Trp 486, Trp 485, Trp 279, Asp 507, and for $\mathrm{Cl} 2$ they include Tyr 224, Arg 522, Pro 519, Pro 407, Met 223, Trp 220 [ 60].

Besides enzymes and channels, chloride binding structures are present in structural proteins such as capsomeres of capsids of a number of viruses (Porcine circovirus type 2 - PCV2). Modelling revealed that chloride ions interact with the capsid in the same place as the genome of this DNA virus and other RNA viruses [61, 62]. Since DNA has negatively charged phosphate groups this looks rather plausible for the negatively charged chloride. It was also found that the concentration of chloride inside the virion exceeded that outside and its outer surface is dominated by the positively charged sodium [63]. Sodium and chloride diffuse inside the capsid through special protein channels more slowly than water does. It was also found that the capsid acts as a selective membrane [64]. Its structure was disrupted in case of insufficient chloride content. Capsomeres made up incorrect virus particles [64].

\section{Enzymes of blood coagulation system and fibrinogen}

High concentration of chloride ions inhibits activation of Glu-plasminogen by urokinase or the tissue plasminogen activator (t-PA) [65]. The inhibition is not observed in a system containing fibrin clot, Glu-plasminogen and t-PA, since fibrin clot is powerful stimulator of Pg activation by t-PA. The chloride ion also inhibits limited proteolysis of the bond Y1605-M1606 of the von Willebrand factor (VWF) by the protease ADAMTS-13 [66]. The chloride stabilizes the resulting conformation of VWF. As a result, VWF presents a significant change in heat capacity which is -1 and $-0.4 \mathrm{kcal} / \mathrm{mol} * \mathrm{~K}$ for the WT and pR1306W A1-A2-A3 domain, respectively [66]. Meanwhile the R1306W type mutation of 2B VWD extinguishes chloride binding to the A1 domain.

Our laboratory also showed that fibrinogen has chloride-binding structures and is able to bind 66 chloride ions per one fibrin molecule. The chloridebinding structures, probably, contain amino acids lysine and arginine residues and are present in the hinge regions of the molecule supercoil connectors and in polymerization sites in the D-, E- and, possibly, the aC-regions of the molecule. It was shown using turbidimetry that the fluoride ion unlike the chloride has no inhibitory effect on fibrin polymerization initiated by thrombin or reptilase under equal ionic strength. Experiments with surface plasmon resonance showed that recognition by our monoclonal antibody FnI-3c of the exposition of the neoantigenic determinant forming in the hinge region of the molecule when fibrinogen turns into fibrin is inhibited by the chloride anion. The data indicate chloride binding regions in the hinge region of the molecule and suggest that chloride binding inhibits the mobility of the fibrinogen molecule, thus slowing down the overall fibrin clot formation [67].

It is hypothesized that the chloride-binding structures of fibrinogen have certain similarity to the analogous structures of plasminogen and are compiled of positively charged arginine, lysine and histidine. Based on the PDB file 4dur of plasminogen, we found that chlorine atoms interact with the positively charged amino acid residues Arg426 and Lys392, which are situated in the fourth kringle domain (Fig. 3). Similarly bound chloride is contained in the second kringle. Further research should clarify the position and structure of chloride-binding structures of fibrinogen and their possible similarity with corresponding plasminogen domains.

In this review, we considered the currently known structures in proteins that bind chloride anions. Common to them is the presence of positively charged amino acids, histidine, arginine, lysine. Chloride-binding sites are often located between domains, in a surface cleft, in a pocket or similar structures. Chloride binding enhances the overall 


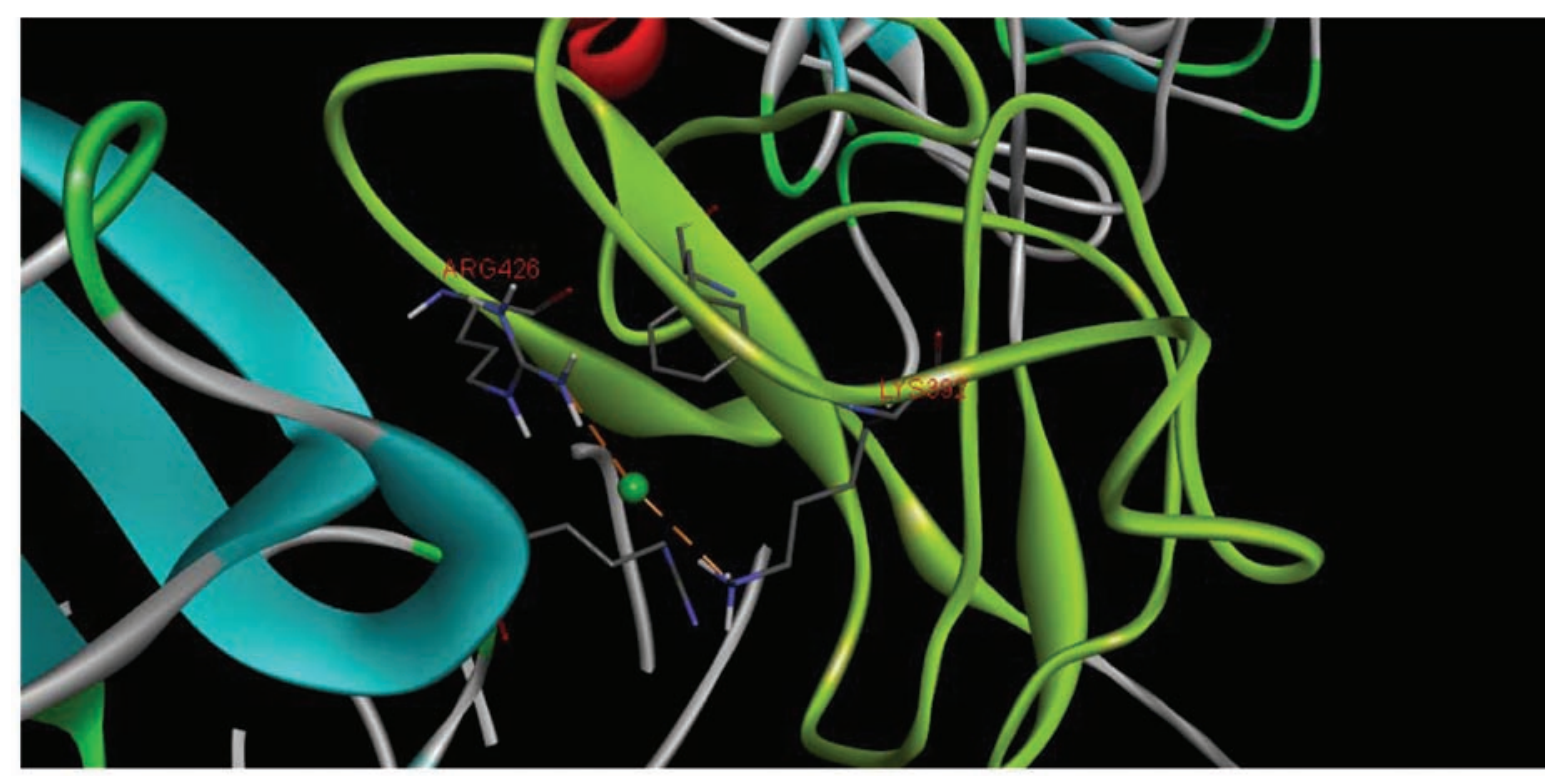

Fig. 3. Structure of the chloride-binding site of plasminogen kringle 4 domain

entropy of the system; in addition, high affinity chloride binding sites are often located in a hydrophobic environment, which enhances electrostatic interactions between chloride and amino acid radicals. In this case, the chloride ion is a stabilizer or switch of the protein conformation. The change in these properties with a change in the chloride concentration allows one to "feel" the concentration of this important anion at the molecular level.

The presence of a chloride-bound sodium ion is also common, which interacts with negatively charged amino acids, causing conformation fixation or a change in the conformation of the entire structure. However, chloride binding structures of the porcinovirus capsid are dynamic and do not lie under the surface of the molecule in the cleft. We also assume that the structures characteristic of fibrinogen are dynamic. Despite the fact that the effect of chloride on them is revealed in non-physiological ranges of chloride concentrations, they are sensitive to chloride and not to fluoride and can be attractive targets for the creation of antithrombotic compounds acting directly on fibrinogen transformation into fibrin. Therefore, further study of the effect of anions on fibrinogen is very promising.

Conflict of interest. Authors have completed the Unified Conflicts of Interest form at http://ukrbiochemjournal.org/wp-content/uploads/2018/12/ coi_disclosure.pdf and declare no conflict of interest.
Funding. This work was supported by basic theme N15 of the Palladin Institute of Biochemistry of NAS of Ukraine "Study of regulation mechanisms of blood coagulation and fibrinolysis interplay with vascular and platelet hemostasis”.

\section{ХЛОРИДЗВ'ЯЗУВАЛЬНІ СТРУКТУРИ, ЇХ РОЛЬ ТА ОРГАНІЗАЦІЯ В ПРОТЕЇНАХ}

\section{Р. Ю. Марунич \\ Г. К. Березницький, Л. В. Пирогова, \\ Г. К. Гоголінська, С. М. Макогоненко

$$
\begin{aligned}
& \text { Інститут біохімії ім. О.В. Палладіна } \\
& \text { НАН України, Київ; } \\
& \text { ®e-mail: rostmarbiotech@gmail.com }
\end{aligned}
$$

Огляд присвячено хлоридзв'язувальним структурам у складі протеїнів бактерій, рослин, вірусів та тварин. Розглянуто будову та амінокислотний склад хлоридзв'язувального сайту та його роль у функціонуванні структурних, регуляторних, транспортних, рецепторних, канальних протеїнів, а також транскрипційних факторів та ензимів. Наведено дані про важливу роль хлоридзв'язувальних структур і аніонів хлориду в полімеризації фібрину.

К л ю ч о в і с ло в а: хлоридзв'язувальний сайт, хлорид-аніон, структура протеїну, фібрин. 


\section{References}

1. Watanabe M, Fukuda A. Development and regulation of chloride homeostasis in the central nervous system. Front Cell Neurosci. 2015; 9: 371.

2. Carugo O. Buried chloride stereochemistry in the Protein Data Bank. BMC Struct Biol. 2014; 14: 19.

3. Bull TE, Halle B, Lindman B. Internal motion at the chloride binding sites of human serum albumin by NMR relaxation studies. FEBS Lett. 1978; 86(1): 25-28.

4. Halle B, Lindman B. Chloride ion binding to human plasma albumin from chlorine-35 quadrupole relaxation. Biochemistry. 1978; 17(18): 3774-3781.

5. Scatchard G, Yap WT. The physical chemistry of protein solutions. XII. The effects of temperature and hydroxide ion on the binding of small anions to human serum albumin. J Am Chem Soc. 1964; 86(17): 3434-3438.

6. Ueno H, Manning JM. The functional, oxygenlinked chloride binding sites of hemoglobin are contiguous within a channel in the central cavity. J Protein Chem. 1992; 11(2): 177-185.

7. Manning JM. Random chemical modification of hemoglobin to identify chloride binding sites in the central dyad axis: their role in control of oxygen affinity. Artif Cells Blood Substit Immobil Biotechnol. 1994; 22(2): 199-205.

8. Chiancone E, Norne JE, Forsén S, Bonaventura J, Brunori M, Antonini E, Wyman J. Identification of chloride-binding sites in hemoglobin by nuclear-magnetic-resonance quadrupolerelaxation studies of hemoglobin digests. Eur $J$ Biochem. 1975; 55(2): 385-390.

9. Prange HD, Shoemaker JL, Westen EA, Horstkotte DG, Pinshow B. Physiological consequences of oxygen-dependent chloride binding to hemoglobin. J Appl Physiol. 2001; 91(1): 33-38.

10. De Rosa MC, Castagnola M, Bertonati C, Galtieri A, Giardina B. From the Arctic to fetal life: physiological importance and structural basis of an 'additional' chloride-binding site in haemoglobin. Biochem J. 2004; 380(Pt 3): 889896.

11. Wolf-Watz M, Bäckström S, Grundström $\mathrm{T}$, Sauer U, Härd T. Chloride binding by the AML1/ Runx1 transcription factor studied by NMR. FEBS Lett. 2001; 488(1-2): 81-84.
12. Bäckström S, Wolf-Watz M, Grundström C, Härd T, Grundström T, Sauer UH. The RUNX1 Runt domain at $1.25 \mathrm{~A}$ resolution: a structural switch and specifically bound chloride ions modulate DNA binding. J Mol Biol. 2002; 322(2): 259-272.

13. Wang Z, Asenjo AB, Oprian DD. Identification of the $\mathrm{Cl}(-)$-binding site in the human red and green color vision pigments. Biochemistry. 1993; 32(9): 2125-2130.

14. Tora AS, Rovira X, Dione I, Bertrand HO, Brabet I, De Koninck Y, Doyon N , Pin JP, Acher F, Goudet C. Allosteric modulation of metabotropic glutamate receptors by chloride ions. FASEB J. 2015; 29(10): 4174-4188.

15. Ogawa H, Qiu Y, Philo JS, Arakawa T, Ogata CM, Misono KS. Reversibly bound chloride in the atrial natriuretic peptide receptor hormonebinding domain: possible allosteric regulation and a conserved structural motif for the chloridebinding site. Protein Sci. 2010; 19(3): 544-557.

16. Hu J, Spiegel AM. Structure and function of the human calcium-sensing receptor: insights from natural and engineered mutations and allosteric modulators. J Cell Mol Med. 2007; 11(5): 908922.

17. Luu P, Acher F, Bertrand HO, Fan J, Ngai J. Molecular determinants of ligand selectivity in a vertebrate odorant receptor. J Neurosci. 2004; 24(45): 10128-10137.

18. Pi M, Faber P, Ekema G, Jackson PD, Ting A, Wang N, Fontilla-Poole M, Mays RW, Brunden KR, Harrington JJ, Quarles LD. Identification of a novel extracellular cationsensing G-protein-coupled receptor. $\mathrm{J}$ Biol Chem. 2005; 280(48): 40201-40209.

19. Acher FC, Selvam C, Pin JP, Goudet C, Bertrand HO. A critical pocket close to the glutamate binding site of mGlu receptors opens new possibilities for agonist design. Neuropharmacology. 2011; 60(1): 102-107.

20. Ogawa H, Qiu Y, Philo JS, Arakawa T, Ogata CM, Misono KS. Reversibly bound chloride in the atrial natriuretic peptide receptor hormonebinding domain: possible allosteric regulation and a conserved structural motif for the chloridebinding site. Protein Sci. 2010; 19(3): 544-557.

21. Bertrand HO, Bessis AS, Pin JP, Acher FC. Common and selective molecular determinants involved in metabotopic glutamate receptor agonist activity. J Med Chem. 2002; 45(15): 3171-3183. 
22. Ogawa H, Qiu Y, Ogata CM, Misono KS. Crystal structure of hormone-bound atrial natriuretic peptide receptor extracellular domain: rotation mechanism for transmembrane signal transduction. J Biol Chem. 2004; 279(27): 28625-28631.

23. Van den Akker F, Zhang X, Miyagi M, Huo X, Misono KS, Yee VC. Structure of the dimerized hormone-binding domain of a guanylyl-cyclasecoupled receptor. Nature. 2000; 406(6791): 101104.

24. He XL, Chow DC, Martick MM, Garcia KC. Allosteric activation of a spring-loaded natriuretic peptide receptor dimer by hormone. Science. 2001; 293(5535): 1657-1662.

25. Charloux A, Piquard F, Doutreleau S, Brandenberger G, Geny B. Mechanisms of renal hyporesponsiveness to ANP in heart failure. Eur J Clin Invest. 2003; 33(9): 769-778.

26. Kalra PR, Anker SD, Coats AJ. Water and sodium regulation in chronic heart failure: the role of natriuretic peptides and vasopressin. Cardiovasc Res. 2001; 51(3): 495-509.

27. Cataliotti A, Boerrigter G, Chen $\mathrm{HH}$, Jougasaki M, Costello LC, Tsuruda T, Lee SC, Malatino LS, Burnett JC Jr. Differential actions of vasopeptidase inhibition versus angiotensinconverting enzyme inhibition on diuretic therapy in experimental congestive heart failure. Circulation. 2002; 105(5): 639-644.

28. Hamasaki N. The role of band 3 protein in oxygen delivery by red blood cells. Indian J Clin Biochem. 1999; 14(1): 49-58.

29. Jennings ML, Passow H. Anion transport across the erythrocyte membrane, in situ proteolysis of band 3 protein, and cross-linking of proteolytic fragments by 4,4'-diisothiocyano dihydrostilbene-2,2'-disulfonate. Biochim Biophys Acta. 1979; 554(2): 498-519.

30. Jentsch TJ, Pusch M. CLC chloride channels and transporters: structure, function, physiology, and disease. Physiol Rev. 2018; 98(3): 1493-1590.

31. Dutzler R, Campbell EB, Cadene M, Chait BT, MacKinnon R. X-ray structure of a $\mathrm{ClC}$ chloride channel at 3.0 A reveals the molecular basis of anion selectivity. Nature. 2002; 415(6869): 287294.

32. Reithmeier RAF, Casey JR, Kalli AC, Sansom MSP, Alguel Y, Iwata S. Band 3, the human red cell chloride/bicarbonate anion exchanger (AE1, SLC4A1), in a structural context. Biochim Biophys Acta. 2016; 1858(7 Pt A): 1507-1532.

33. Yamaguchi T, Ikeda Y, Abe Y, Kuma H, Kang D, Hamasaki N, Hirai T. Structure of the membrane domain of human erythrocyte anion exchanger 1 revealed by electron crystallography. $\mathrm{J} \mathrm{Mol} \mathrm{Biol}$. 2010; 397(1): 179-189.

34. Hirai T, Hamasaki N, Yamaguchi T, Ikeda Y. Topology models of anion exchanger 1 that incorporate the anti-parallel V-shaped motifs found in the EM structure. Biochem Cell Biol. 2011; 89(2): 148-156.

35. Bonar P, Schneider HP, Becker HM, Deitmer JW, Casey JR. Three-dimensional model for the human $\mathrm{Cl}^{-} / \mathrm{HCO}_{3}{ }^{-}$exchanger, AE1, by homology to the E. coli ClC protein. J Mol Biol. 2013; 425(14): 2591-2608.

36. Barneaud-Rocca D, Etchebes C, Guizouarn H. Structural model of the anion exchanger 1 (SLC4A1) and identification of transmembrane segments forming the transport site. $\mathrm{J}$ Biol Chem. 2013; 288(37): 26372-26384.

37. Jennings ML, Anderson MP. Chemical modification and labeling of glutamate residues at the stilbenedisulfonate site of human red blood cell band 3 protein. J Biol Chem. 1987; 262(4): 1691-1697.

38. Jennings ML, Smith JS. Anion-proton cotransport through the human red blood cell band 3 protein. Role of glutamate 681. J Biol Chem. 1992; 267(20): 13964-13971.

39. Chernova MN, Jiang L, Crest M, Hand M, Vandorpe DH, Strange K, Alper SL. Electrogenic sulfate/chloride exchange in Xenopus oocytes mediated by murine AE1 E699Q. J Gen Physiol. 1997; 109(3): 345-360.

40. Müller-Berger S, Karbach D, Kang D, Aranibar N, Wood PG, Rüterjans H, Passow H. Roles of histidine 752 and glutamate 699 in the $\mathrm{pH}$ dependence of mouse band 3 proteinmediated anion transport. Biochemistry. 1995; 34(29): 9325-9332.

41. Shnitsar V, Li J, Li X, Calmettes C, Basu A, Casey JR, Moraes TF, Reithmeier RAF. A substrate access tunnel in the cytosolic domain is not an essential feature of the solute carrier 4 (SLC4) family of bicarbonate transporters. $J$ Biol Chem. 2013; 288(47): 33848-33860.

42. Tavoulari S,Rizwan AN, Forrest LR, Rudnick G. Reconstructing a chloride-binding site in a bacterial neurotransmitter transporter 
homologue. J Biol Chem. 2011; 286(4): 28342842

43. Forrest LR, Tavoulari S, Zhang YW, Rudnick G, Honig B. Identification of a chloride ion binding site in $\mathrm{Na}^{+} / \mathrm{Cl}$-dependent transporters. Proc Natl Acad Sci USA. 2007; 104(31): 12761-12766.

44. Zomot E, Bendahan A, Quick M, Zhao Y, Javitch JA, Kanner BI. Mechanism of chloride interaction with neurotransmitter:sodium symporters. Nature. 2007; 449(7163): 726-730.

45. Forrest LR, Zhang YW, Jacobs MT, Gesmonde J, Xie L, Honig BH, Rudnick G. Mechanism for alternating access in neurotransmitter transporters. Proc Natl Acad Sci USA. 2008; 105(30): 10338-10343.

46. Forrest LR, Rudnick G. The rocking bundle: a mechanism for ion-coupled solute flux by symmetrical transporters. Physiology. 2009; 24: 377-386.

47. Kantcheva AK, Quick M, Shi L, Winther AM, Stolzenberg S, Weinstein H, Javitch JA, Nissen P. Chloride binding site of neurotransmitter sodium symporters. Proc Natl Acad Sci USA. 2013;110(21):8489-8494.

48. Ben-Yona A, Bendaha A, Kanner BI. A glutamine residue conserved in the neurotransmitter:sodiu m:symporters is essential for the interaction of chloride with the GABA transporter GAT-1. $J$ Biol Chem. 2011; 286(4): 2826-2833.

49. Marvizón JC, Skolnick P. Anion regulation of $[3 \mathrm{H}]$ strychnine binding to glycine-gated chloride channels is explained by the presence of two anion binding sites. Mol Pharmacol. 1988; 34(6): 806-813.

50. Ong PL, Chuang TT, Wang TF, Lin LL. Identification of critical amino acid residues for chloride binding of Bacillus licheniformis trehalose-6-phosphate hydrolase. Biologia. 2014;69(1): 1-9.

51. Piala AT, Moon TM, Akella R, He H, Cobb MH, Goldsmith EJ. Chloride sensing by WNK1 involves inhibition of autophosphorylation. Sci Signal. 2014; 7(324): ra41.

52. Hirano T, Mogi T, Tsubaki M, Hori H, Orii Y, Anraku Y. A novel chloride-binding site modulates the heme-copper binuclear center of the Escherichia coli bo-type ubiquinol oxidase. J Biochem. 1997; 122(2): 430-437.

53. Soubrier F, Alhenc-Gelas F, Hubert C, Allegrini J, John M, Tregear G, Corvol P. Two putative active centers in human angiotensin
I-converting enzyme revealed by molecular cloning. Proc Natl Acad Sci USA. 1988; 85(24): 9386-9390.

54. Ehlers MR, Fox EA, Strydom DJ, Riordan JF. Molecular cloning of human testicular angiotensin-converting enzyme: the testis isozyme is identical to the C-terminal half of endothelial angiotensin-converting enzyme. Proc Natl Acad Sci USA. 1989; 86(20): 77417745.

55. Hubert C, Houot AM, Corvol P, Soubrier F. Structure of the angiotensin I-converting enzyme gene. Two alternate promoters correspond to evolutionary steps of a duplicated gene. $J$ Biol Chem. 1991; 266(23): 15377-15383.

56. Natesh R, Schwager SL, Sturrock ED, Acharya KR. Crystal structure of the human angiotensin-converting enzyme-lisinopril complex. Nature. 2003; 421(6922): 551-554.

57. Natesh R, Schwager SL, Evans HR, Sturrock ED, Acharya KR. Structural details on the binding of antihypertensive drugs captopril and enalaprilat to human testicular angiotensin I-converting enzyme. Biochemistry. 2004; 43(27): 8718-8724.

58. Tzakos AG, Galanis AS, Spyroulias GA, Cordopatis P, Manessi-ZoupaE, Gerothanassis IP. Structure-function discrimination of the $\mathrm{N}$ - and C- catalytic domains of human angiotensinconverting enzyme: implications for Clactivation and peptide hydrolysis mechanisms. Protein Eng. 2003; 16(12): 993-1003.

59. Liu X, Fernandez M, Wouters MA, Heyberger S, Husain A. $\operatorname{Arg}(1098)$ is critical for the chloride dependence of human angiotensin I-converting enzyme C-domain catalytic activity. $J$ Biol Chem. 2001; 276(36): 33518-33525.

60. Moiseeva NA, Binevski PV, Baskin II, Palyulin VA, Kost OA. Role of two chloridebinding sites in functioning of testicular angiotensin-converting enzyme. Biochemistry (Mosc). 2005; 70(10): 1167-1172.

61. Larsson DS, van der Spoel D. Screening for the location of RNA using the chloride ion distribution in simulations of virus capsids. $J$ Chem Theory Comput. 2012; 8(7): 2474-2483.

62. Tarasova E, Farafonov V, Khayat R, Okimoto N, Komatsu TS, Taiji M, Nerukh D. All-Atom Molecular Dynamics Simulations of Entire Virus Capsid Reveal the Role of Ion Distribution in Capsid's Stability. J Phys Chem Lett. 2017; 8(4): 779-784. 
63. Tarasova E, Farafonov V, Taiji M, Nerukh D. Details of charge distribution in stable viral capsid. J Mol Liquids. 2018; 265: 585-591.

64. Tarasova E, Korotkin I, Farafonov V, Karabasov S, Nerukh D. Complete virus capsid at all-atom resolution: Simulations using molecular dynamics and hybrid molecular dynamics/ hydrodynamics methods reveal semipermeable membrane function. J Mol Liquids. 2017; 245: 109-114.

65. Gaffney PJ, Urano T, de Serrano VS, MahmoudAlexandroni M, Metzger AR, Castellino FJ. Roles for chloride ion and fibrinogen in the activation of [Glu1]plasminogen in human plasma. Proc Natl Acad Sci USA. 1988; 85(10): 3595-3598.
66. De Cristofaro R, Peyvandi F, Baronciani L, Palla R, Lavoretano S, Lombardi R, Di Stasio E, Federici AB, Mannucci PM. Molecular mapping of the chloride-binding site in von Willebrand factor (VWF): energetics and conformational effects on the VWF/ADAMTS-13 interaction. $J$ Biol Chem. 2006; 281(41): 30400-30411.

67. Pyrogova LV, Bereznitsky G., Gogolinskya GK, Platonova TM, Kolesnikova IM, Masenko OO, Marunych RY., Tsap PYu, Ushenin YuV, Makogonenko EM, Lugovskoi EV. Comparative analysis of the effect of chlorine and fluorine ions on the polymerization of fibrin. Ukr Biochim J. 2019; 91(6): 27-37. 